\title{
Studies on the In Vitro Behavior of
}

\section{Agammaglobulinemic Lymphocytes}

\author{
S. R. Cooperband, F. S. Rosen, and S. Kibrick \\ From the 5th and 6th (Boston University) Medical Services, Boston City Hospital, Evans \\ Memorial Department of Clinical Research, University Hospital, Department of Medicine \\ and Microbiology, Boston University School of Medicine, and Department of Medicine, \\ Children's Hospital Medical Center, Department of Pediatrics, Harvard Medical School, \\ Boston, Massachusetts 02118
}

A в S T R A C T Circulating lymphocytes from patients with congenital X-linked agammaglobulinemia, sporadic congenital agammaglobulinemia, and acquired agammaglobulinemia have been cultured in vitro. They have been shown to proliferate in a normal manner under stimulus of phytohemagglutinin and antigens to which the patient was sensitized. Agammaglobulinemic cells have been shown to synthesize protein at a rate similar to that of normal cells, and the character of the extracellular protein produced is also similar. Agammaglobulinemic lymphocytes have been found to produce a small quantity of immunoglobulin G, similar to that found in normal cell cultures. The quantity of immunoglobulin produced may be increased by exposure of the cells to phytohemagglutinin. From these data, it appears that the basic lesion responsible for agammaglobulinemia is not a deficiency in lymphocyte-mediated antigen recognition or cellular proliferation. It would also appear that the basic deficiency in these disorders does not involve the structural or regulatory genes necessary for the synthesis of immunoglobulins. By exclusion, the pathogenesis of the deficiency would appear to involve cells other than circulating lymphocytes.

This paper was presented in part at the 48th annual meeting of the American Society for Clinical Investigation, 1 May 1966.

Address requests for reprints to Dr. Sidney R. Cooperband, Boston University School of Medicine, 15 Stoughton Street, Boston, Mass. 02118.

Received for publication 25 April 1967 and in revised form 10 November 1967.

\section{INTRODUCTION}

The clinical disorders which are characterized by defective synthesis of gammaglobulin could result from genetic deficiencies in any of the complex events leading to the formation of circulating antibodies. These events may be classified into three general categories: $(a)$ recognition of foreign substances as antigens; $(b)$ proliferation and differentiation of immunocompetent cells; and $(c)$ the synthesis of immunoglobulins. Normal blood lymphocytes in tissue culture recently have been demonstrated to be competent in each of these functions. Pearmain, Lycette, and Fitzgerald (1), Shrek (2), and many others have demonstrated that human blood lymphocytes in cultures are capable of proliferation in the presence of antigens to which the donor has had a previous immunologic response. Lymphocyte cultures are capable of synthesizing immunoglobulins and the quantity of immunoglobulins produced may be increased by a variety of agents, especially the bean protein, phytohemagglutinin (PHA) (3-5). The circulating lymphocytes from 17 agammaglobulinemic patients have been examined to determine their ability to recognize antigens and to proliferate when exposed to these substances. The maximal proliferative response to PHA, and the quantity and character of the protein that is synthesized by these cells have also been studied. The studies with cells from agammaglobulinemic individuals have been compared with similar studies utilizing cells from normal donors. 


\section{METHODS}

Cell donors were 23 healthy laboratory personnel in the age range of $18-50$ and 17 agammaglobulinemic individuals in the age range of $2-38$ (see Table I). The latter population included 14 patients with X-linked congenital agammaglobulinemia, 1 patient with sporadic congenital agammaglobulinemia, and 2 patients with acquired agammaglobulinemia. All the agammaglobulinemic patients had been receiving replacement $\boldsymbol{\gamma}$-globulin, except patients War and $\mathrm{Kim}$. The quantity of $\gamma$-globulin in the serum of these patients is given in Table I. All had insignificant quantities of $\gamma \mathrm{M}$ and $\gamma \mathrm{A}$. Serum immunoglobulin levels were determined by the method of Fahey and Lawrence (6). Serum levels as follows were accepted as normal : $\gamma \mathrm{G}, 1.26 \pm 0.27 \mathrm{~g} / 100 \mathrm{ml} ; \gamma \mathrm{A}, 394 \pm 91$ $\mathrm{mg} / 100 \mathrm{ml} ; \gamma \mathrm{M}, 116 \pm 55 \mathrm{mg} / 100 \mathrm{ml}$. All patients had essentially normal circulating leukocytes except $P$. Sal who had approximately $25 \%$ bizarre monocytoid cells which defied classification.

Plasma rich in lymphocytes was prepared by the method of Mellman (7). Heparinized blood in a $50 \mathrm{ml}$ syringe was held at a $45^{\circ}$ angle for 1-2 hr. The plasma was then expressed through a bent No. 19 needle, and centrifuged at $300 \mathrm{~g}$ for $10 \mathrm{~min}$. The sedimented cells were washed two to three times with incubation medium and suspended to give a final concentration of either 1 or $2 \times 10^{8}$ lymphocytes $/ \mathrm{ml}$. The percentage of lymphocytes in these cultures varied slightly with each donor, but fell in the range of $60-90 \%$ with approximately a $30 \%$ yield from the blood. In one early study, using $\mathrm{D}$. $\mathrm{McD}$ cells, 5\% dextran was used to accelerate red blood cell sedimentation. This was later found to reduce the proliferative response of the isolated lymphocytes and was not, thereafter used.

TABLE I

Patients Studied

\begin{tabular}{|c|c|c|c|c|c|c|c|}
\hline \multirow[b]{2}{*}{ Patients } & \multirow[b]{2}{*}{ Sex } & \multirow[b]{2}{*}{ Age } & \multirow{2}{*}{$\begin{array}{c}\text { Type of } \\
\text { agamma- } \\
\text { globulinemia }\end{array}$} & \multicolumn{4}{|c|}{$\begin{array}{c}\text { Serum immunoglobulin } \\
\text { level, \% normal }\end{array}$} \\
\hline & & & & $\gamma \mathrm{G}$ & $\gamma \mathbf{A}$ & $\gamma \mathbf{M}$ & $\gamma \mathrm{D}^{*}$ \\
\hline D. $\mathrm{McD}$ & $\mathbf{M}$ & 12 & Congenital & $18 \ddagger$ & $<1$ & $<1$ & $<1$ \\
\hline R. Caou & $\mathbf{M}$ & 8 & Congenital & $20 \ddagger$ & $<1$ & 3 & $<1$ \\
\hline R. Lem & $\mathbf{M}$ & 5 & Congenital & $10 \ddagger$ & $<1$ & $<1$ & $<1$ \\
\hline J. War & $\mathbf{M}$ & 14 & Congenital & $<1$ & $<1$ & $<1$ & ND \\
\hline G. Ent & $\mathbf{M}$ & 11 & Congenital & $19 \ddagger$ & $<1$ & $<1$ & $<1$ \\
\hline H. Torr & $\mathbf{M}$ & 12 & Congenital & $18 \ddagger$ & $<1$ & $<1$ & $<1$ \\
\hline E. Anu & $\mathbf{M}$ & 15 & Congenital & $25 t$ & $<1$ & $<1$ & ND \\
\hline J. Jack & $\mathbf{M}$ & 16 & Congenital & $6 \ddagger$ & $<1$ & $<1$ & ND \\
\hline J. Wall & $\mathbf{M}$ & 21 & Congenital & $18 \ddagger$ & $<1$ & $<1$ & ND \\
\hline S. Stu & $\mathbf{M}$ & 6 & Congenital & $15 \ddagger$ & $<1$ & $<1$ & $<1$ \\
\hline J. Stu & $\mathbf{M}$ & 8 & Congenital & $17 \ddagger$ & $<1$ & $<1$ & ND \\
\hline G. Kim & $\mathbf{M}$ & 3 & Congenital & $<1$ & $<1$ & $<1$ & ND \\
\hline R. Nels & $\mathbf{M}$ & 10 & Congenital? & $8 \ddagger$ & $<1$ & $<1$ & ND \\
\hline E. Fitz & $\mathbf{M}$ & 9 & Congenital? & $12 \ddagger$ & 4 & 5 & $<1$ \\
\hline P. Sal & $\mathbf{F}$ & 2 & Sporadic & $28 \ddagger$ & $<1$ & 2 & ND \\
\hline T. She & $\mathbf{M}$ & 38 & Acquired & 87 & $<1$ & 8 & $<1$ \\
\hline S. Bet & F & 26 & Acquired & $10 \ddagger$ & $<1$ & $<1$ & ND \\
\hline
\end{tabular}

ND, not done.

* Done by Dr. John Fahey.

$\ddagger$ Receiving exogenous $\gamma$-globulin.
Medium and incubation conditions. The incubation medium for these studies consisted of medium 199 with Earle's salts (Microbiological Associates, Inc., Bethesda, Md.), 25\% serum, and antibiotics (200 $U$ of penicillin/ $\mathrm{ml} ; 200 \mu \mathrm{g}$ of streptomycin $/ \mathrm{ml}$ ). Calf serum was employed in cultures where deoxyribonucleic acid (DNA) synthesis was measured. In cultures for measurement of protein synthesis by lymphocytes, human serum from type $\mathrm{AB}$ donors was employed. The different sera produced only slight differences in DNA and protein synthesis (8). For studies on DNA synthesis, carrier free sodium phosphate- ${ }^{32} \mathrm{P}$ was added to cultures containing $1 \times 10^{6}$ lymphocytes $/ \mathrm{ml}$ at $3 \mu \mathrm{c} / \mathrm{ml}$ to a specific activity of approximately $3.6 \mathrm{mc} / \mathrm{mmole}$ of phosphate. Protein synthesis was studied with leucine-1- ${ }^{14} \mathrm{C}$ (New England Nuclear Corp., Boston, Mass.) as a precursor in cultures containing $2 \times 10^{6}$ lymphocytes $/ \mathrm{ml}$. This was added at $5 \mu \mathrm{c} / \mathrm{ml}$ to give a final specific activity of $6.1 \mathrm{mc} /$ mmoles of 1 -leucine. Previous experiments ${ }^{1}$ have shown that this specific activity does not vary significantly during the 8 days of culture. Phytohemagglutinin $M$ (Difco Laboratories, Detroit, Mich.) was added to designated cultures at a volume of $0.03 \mathrm{ml} / \mathrm{ml}$ of cell suspension. One batch lot (No. 467303) of PHA was employed. A dosage curve for this lot was determined with both normal cells and cells from agammaglobulinemic individuals. $0.03 \mathrm{ml}$ of PHA solution $/ \mathrm{ml}$ of cell suspension was found to give optimum stimulation of DNA synthesis. A variety of antigens were added to different cultures. Tetanus toxoid, in highly purified form (9) was donated by the Institute of Laboratories of the Massachusetts Department of Public Health and added to give a final concentration between 10 and $100 \mathrm{Lf} \mathrm{U} / \mathrm{ml}$. Diphtheria toxoid obtained from the same source was used to yield a final concentration between $15-45 \mathrm{Lf} \mathrm{U} / \mathrm{ml}$. Neither of the antigen preparations contained any preservative, and each preparation was shown to be free of cytotoxic effects. Response between allogeneic leukocytes was assayed with mixtures of equal numbers of cells from two donors. In some of these experiments, one of the cell populations was killed by repeated $(3-5 \times)$ freeze-thawing.

Between 2 and $15 \mathrm{ml}$ of cell suspensions were placed in 2 or $5 \mathrm{dr}$ screw-capped vials and incubated at $36^{\circ} \mathrm{C}$, in water-vapor-saturated $5 \% \quad \mathrm{CO}_{2}-95 \%$ air, with caps loosely applied. At varying intervals, cells were dispersed by pipetting and duplicate aliquots were removed. The samples concerned with protein synthesis were centrifuged at $500 \mathrm{~g}$ at $4^{\circ} \mathrm{C}$ for $10 \mathrm{~min}$, and the cells and cellfree superntant were stored at $-20^{\circ} \mathrm{C}$ until analyzed. The samples concerned with DNA synthesis were stored without separation of cells and supernatant.

Radioactive analysis- ${ }^{32} \mathrm{P} .{ }^{32} \mathrm{PO}_{4}$ incorporation into DNA and acid soluble nucleotides was determined according to the method of Kahan (10). Digestion of the frozen and thawed cellular preparation with pancreatic ribonuclease (Worthington Biochemical Corporation, Freehold, N. J.) failed to alter significantly the re-

1 Cooperband, S. R., A. J. Nahmias, and S. Kibrick. Kinetics of protein synthesis in human lymphocytes in culture. Submitted for publication. 
covery of "DNA" radioactivity. The samples were plated on Millipore filters HA ( $0.45 \mathrm{~m} \mu$ pore size), attached to $15 / 16$ inch planchets, and counted in the Tracerlab Omniguard end window Geiger counter. ${ }^{32} \mathrm{P}$ efficiency was determined at $29 \%$ under these circumstances.

In order to determine that the apparent rate of ${ }^{32} \mathrm{P}$ incorporation into DNA reflected the true rate of synthesis, it was necessary to determine that the ${ }^{32} \mathrm{P}$-labeled precursor pool was constant. In control cultures, and in those cultures stimulated by antigens, there was a rapid increase in the specific activity of the acid soluble ${ }^{32} \mathrm{P}$ labeled nucleotide pool within the first $24 \mathrm{hr}$ of culture, but thereafter the specific activity of radioactive nucleotides remained constant. Cultures stimulated with PHA, however, demonstrated a more rapid and quantitatively greater rise in the acid soluble ${ }^{32} \mathrm{P}$ nucleotides. This was maximum at $24 \mathrm{hr}$ and then fell rapidly, so that after 48$72 \mathrm{hr}$ in the cultures the specific activity of the ${ }^{32} \mathrm{P}$ pool was only two-thirds that of the unstimulated cultures. After $72 \mathrm{hr}$ the acid soluble pool in the PHA cultures became more stable.

Radioactive analysis of ${ }^{14} \mathrm{C}$-labeled protein. Extensive dialysis against phosphate-buffered saline containing $1 \%$ casamino acids was used to remove nonincorporated leucine $-{ }^{14} \mathrm{C}$ from the newly synthesized supernate protein. Variable amounts of human serum were added to the dialyzed preparations to provide markers for subsequent biochemical examinations. Total ${ }^{14} \mathrm{C}$-labeled protein was determined after precipitataion with cold $0.3 \mathrm{~N}$ perchloric acid containing $1 \%$ caseamino acids. The precipitate was centrifuged at $800 \mathrm{~g}$ and washed two times. Lipids were extracted with alcohol-ether-chloroform $(3: 3: 1)$ at $37^{\circ} \mathrm{C}$ for $30 \mathrm{~min}$; polynucleotides were twice hydrolyzed and extracted with hot $\left(75^{\circ} \mathrm{C}\right) 0.3 \mathrm{~N}$ perchloric acid for $15 \mathrm{~min}$; and the protein precipitate finally plated and washed on Millipore HA filters. Filters were glued to $15 / 16$ inch aluminum plachets and counted as above. Counts were corrected for self-absorption to infinite thinness by an empirically derived curve. No correction was found necessary for $6 \mathrm{mg}$ or less of protein precipitate, and most of the planchets were analyzed with less than $6 \mathrm{mg}$ of protein plated. Counting efficiency under these circumstances was determined to be $10 \%$.

Biochemical analysis of supernatant protein. Three biochemical methods were employed to characterize the ${ }^{14} \mathrm{C}$ labeled protein found in the extracellular medium of these cell cultures. Electrophoresis of the prepared supernatant was carried out in $0.1 \mathrm{M}$ barbital buffer, $\mathrm{pH} 8.6$, on No. 1 Whatman filter paper and using a Beckman Spinco apparatus (model R) at $60 \mathrm{v}$ (30 mamp) for $24 \mathrm{hr} .25 \mu \mathrm{l}$ of the supernatant was applied with the Beckman applicator. After electrophoresis, strips were heat fixed, washed extensively in methanol, and stained with bromphenol blue. The strips were scanned optically in the Beckman analytrol, and were analyzed for the distribution of radioactive protein in the Vanguard Model 880 scanner using 4 pi geometry. Radioactive analysis was performed through a $1 \mathrm{~cm}$ slit at a movement rate of 6 inches $/ \mathrm{hr}$. The optical and radioactive analysis were aligned and superimposed.
$O$ - (Diethylaminoethyl-) cellulose (DEAE-cellulose) chromatography of the prepared supernatant protein was carried out according to the method of Fahey, McCay, and Goulian (11). $1 \mathrm{ml}$ samples of the supernatants were dialyzed against $0.01 \mathrm{~m}$ phosphate buffer, $\mathrm{pH} 8$, and applied to $1.2 \times 27 \mathrm{~cm}$ DEAE-cellulose columns equilibrated with this buffer. A concave gradient to $0.3 \mathrm{M}$ phosphate buffer, convex to $\mathrm{pH} 5$ was then applied. Serial $3-\mathrm{ml}$ fractions were collected and their optical density at 280 $\mathrm{m} \mu$ was used to determine the distribution of protein. Aliquots were subsequently plated on aluminum planchets for assay in a Tracerlab Omniguard counter to determine the distribution of radioactive proteins. There was a concave decrease in counting efficiency throughout the entire gradient from 8 to $4 \%$, and each sample was individually adjusted to identical $8 \%$ counting efficiencies using the derived efficiency curve.

Ultracentrifugation in sucrose saline was carried out by a modification of the method of Edelman, Kunkel, and Franklin (12). A linear gradient from 10 to $40 \%$ sucrose in phosphate-buffered saline was prepared in $5-\mathrm{ml}$ cellulose acetate tubes of the Spinco SW 39 head and overlaid with $0.5 \mathrm{ml}$ of the prepared supernatants. The tubes were centrifuged at $39,000 \mathrm{rpm}$, for $24 \mathrm{hr}$ in the Spinco model L ultracentrifuge. 4-drop fractions were collected through a No. 22 needle inserted in the bottom of each tube and diluted with $2 \mathrm{ml}$ of water, optical density at $280 \mathrm{~m} \mu$ was recorded, and the aliquots were plated and assayed for radioactivity. Variations in counting efficiency were adjusted as above.

Immunochemical isolation of $I g G$. We performed isolation of the newly synthesized $\gamma \mathrm{G}$ by immunocoprecipitation using rabbit anti-human $\gamma \mathrm{G}$ globulin and carrier $\gamma \mathrm{G}$ globulin. A precipitin curve characteristic for the antiserum was determined and a precipitate reaction at threefourths the antigenic concentration necessary for equivalence was used to precipitate the newly synthesized $\gamma \mathrm{G}$ from the medium. To remove protein which might be nonspecifically absorbed by the immunoprecipitate, two heterologous precipitin reactions were carried out before the specific coprecipitation. Rabbit anti-bovine serum albumin (anti-BSA) and (or) rabbit anti-egg albu$\min$ (anti-Ea) at equivalence with their specific antigens were used for the nonspecific coprecipitates. These counts averaged $18.6 \%$ of the specific coprecipitates.

\section{RESULTS}

DNA synthesis. The quantity of DNA synthesized by both normal and agammaglobulinemic cell cultures was determined at varying intervals. Typical responses are seen in Fig. 1. Unstimulated cultures from both groups incorporated ${ }^{32} \mathrm{P}$ into the DNA fraction during the first few days of culture, but generally not thereafter. Both cell populations demonstrated a marked stimulation of ${ }^{32} \mathrm{P}$ incorporation into DNA upon exposure to PHA. This stimulation was not seen until two 


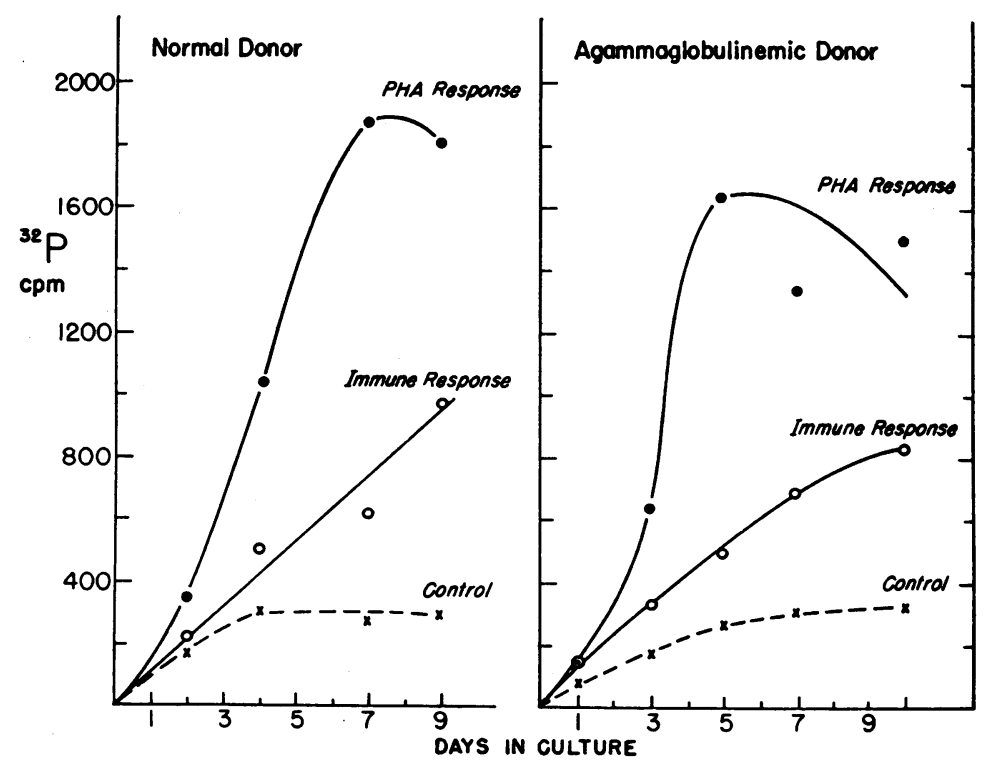

FIGURE 1 Incorporation of ${ }^{22} \mathrm{PO}_{4}$ into DNA by blood lymphocytes during culture. Normal donor cells are seen to the left; agammaglobulinemic cells to the right. Control cultures contained only incubation medium; stimulated cultures contained either phytohemagglutinin (PHA) or diphtheria toxoid $(30 \mathrm{Lf} \mathrm{U} / \mathrm{ml})$. days of culture, and was maximal during the following 1-2 days. The addition of antigens, with which the donor had had previous immunologic experiences, also stimulated ${ }^{32} \mathrm{P}$ incorporation into DNA in both populations. Specific antigenic stimulation produced a linear accumulation of ${ }^{32} \mathrm{P}$ into DNA throughout the 7-10 day period of the usual cultures. Antigens to which the donor was not immune produced ${ }^{32} \mathrm{P}$ incorporation rates virtually the same as in the unstimulated controls.

Proliferative response to antigens and $P H A$ stimulation. In order to compare the intensity of

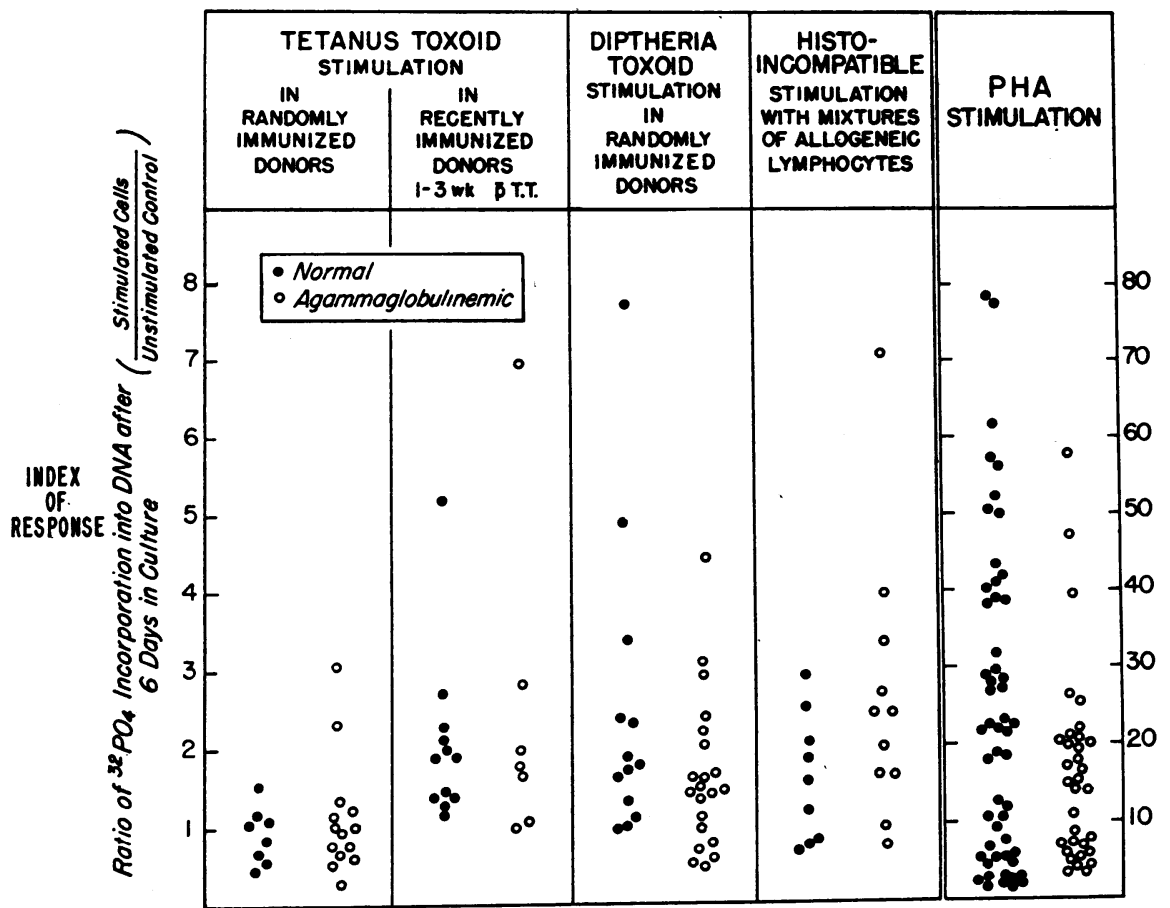

FIGURE 2 Intensity of the proliferative response in normal and agammaglobulinemic lymphocyte cultures to stimulation with various antigens, and with phytohemagglutinin. $\bar{p}$ t.t., post immunization with tetanus toxoid. 
the proliferative responses between cultures, we established an "index of response." This was calculated as the maximum response (independent of the necessary dosage of antigen) divided by the unstimulated control culture. A failure to respond would give an index value of one. The "index of response" for the agammaglobulinemic population and the normal donors are compiled in Fig. 2. Previous investigations with lymphocytes from normal donors have demonstrated that the intensity of a specific proliferative response is partly dependent upon the dose of antigen in the culture. ${ }^{2}$ For this reason, cells from both normal and agammaglobulinemic individuals were also cultured with varying doses of antigen. Only a maximal response was used in these calculations. The specific response to tetanus toxoid was generally minimal in both populations unless the patients had been given tetanus toxoid within 1-3 wk before testing. There was a proliferative response to diphtheria toxoid in most of the patients studied without immediately prior immunization. There was an intense response between histoincompatible (allogeneic) lymphocytes in the culture. There was no apparent difference between the different classes of agammaglobulinemic patients studied. The unusually high responses occurred in cultures from patients with congenital X-linked agamma-

${ }^{2}$ Cooperband, S. R., and S. Kibrick. In preparation. globulinemia. Only two patients with acquired, and one patient with sporadic agammaglobulinemia were examined, and these responses fell among the lower values. Statistical examination by simple $t$ test revealed no significant differences between the response of the two populations to any of the antigens tested: (a) Tetanus toxoid stimulation in randomly immunized donors (normal $\bar{x} 0.92$ $\pm \mathrm{SE} 0.13$ vs. agammaglobulinemic $\bar{x} 1.11 \pm \mathrm{sE}$ 0.20) $t=0.6577, \mathrm{P}>0.25$. (b) Tetanus toxoid stimulation in recently immunized donors (normal $\bar{x} 2.06 \pm$ sE 0.24 vs. agammaglobulinemic $\bar{x} 2.47$ $\pm \mathrm{SE} 0.80) \mathrm{t}=0.635, P>0.35$. (c) Diphtheria toxoid stimulation (normal $\bar{x} 2.10 \pm \mathrm{SE} 0.35$ vs. agammaglobulinemic $\bar{x} 1.55 \pm \mathrm{SE} 0.21) t=1.27$, $P>0.1$. (d) Histoincompatible stimulation (normal $\bar{x} 1.98 \pm$ SE 0.26 vs. agammaglobulinemic $\bar{x}$ $2.62 \pm \mathrm{SE} 0.53) t=1.15, P>0.15$.

In order to estimate any alteration in the capacity of agammaglobulinemic lymphocyte cells for nonspecific proliferation, we determined the incorporation of ${ }^{32} \mathrm{P}$ into DNA after maximal stimulation with PHA The time period of 6 days in culture was chosen, since most cultures demonstrated a plateau in ${ }^{32} \mathrm{P}$ incorporation by that time period. The collected data for 33 agammaglobulinemic and 53 normal cultures is seen in Fig. 2. There was a large difference between the mean "indices of response" observed in the two populations (nor-

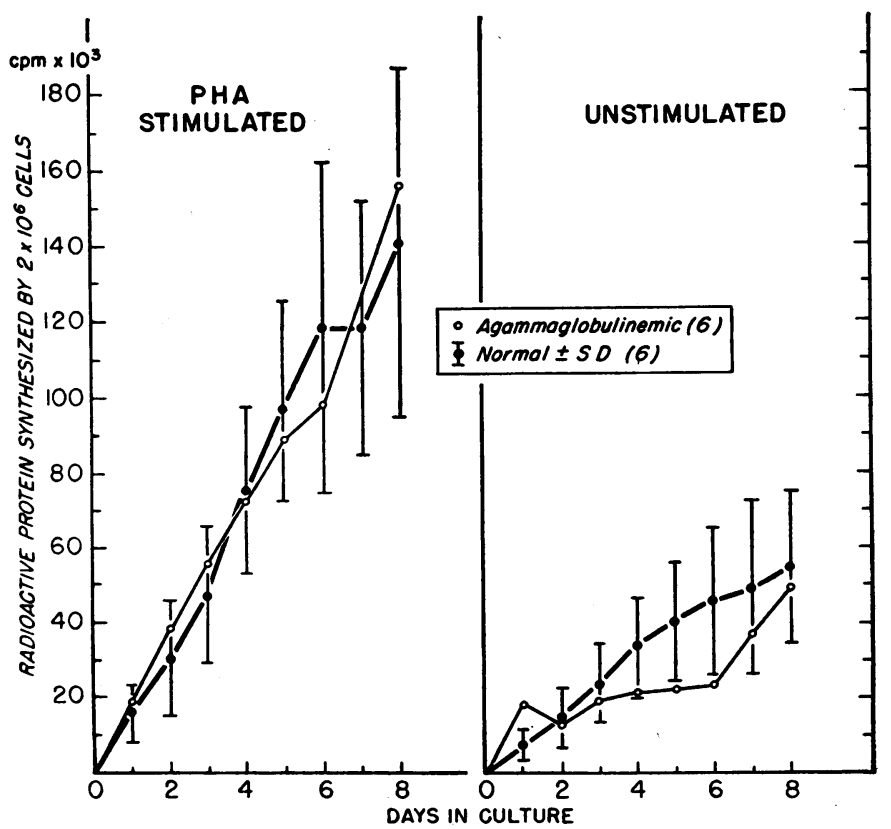

840
S. R. Cooperband, F. S. Rosen, and S. Kibrick
Figure 3 Accumulation of total newly synthesized protein in cultures of normal and agammaglobulinemic lymphocytes (cells and supernatants). Cultures stimulated with phytohemagglutinin on left, unstimulated cultures on right. 


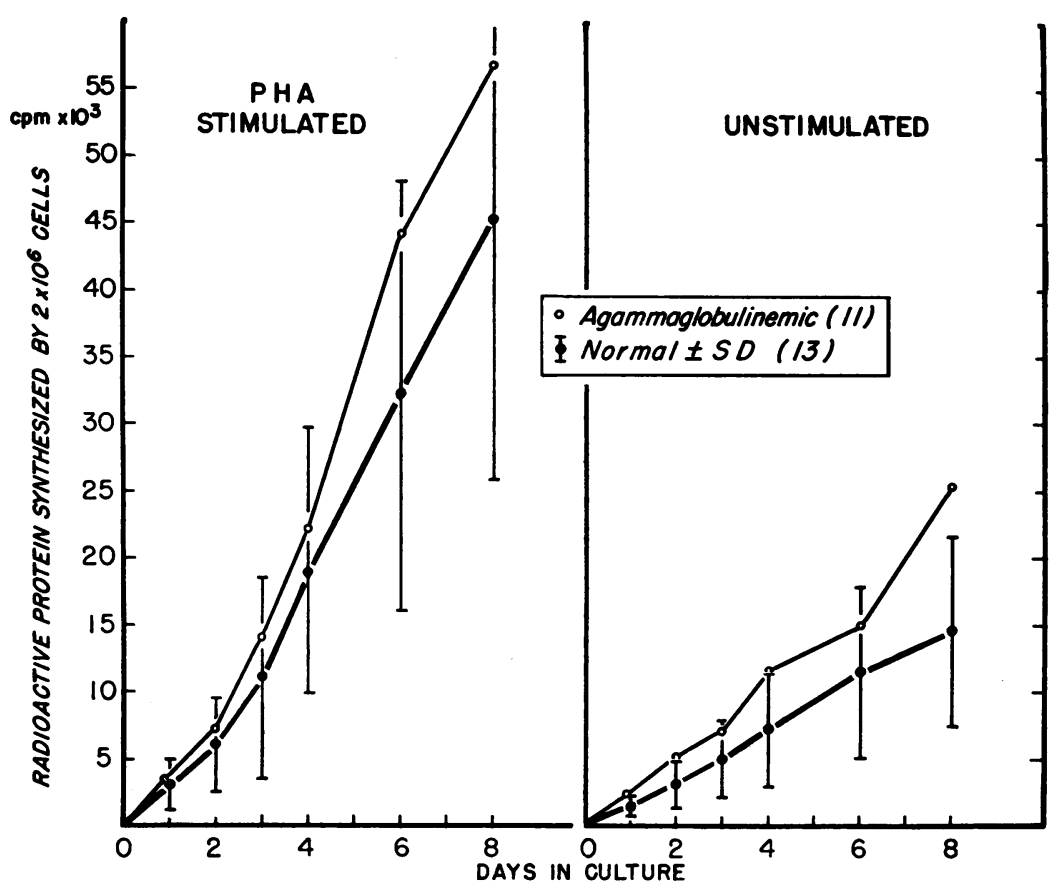

FIGURE 4 Accumuation of newly synthesized protein in the supernatant of normal and agammaglobulinemic lymphocyte cultures. Cultures stimulated with phytohemagglutinin on left, unstimulated cultures right.

$\mathrm{mal}=24.0 \pm \mathrm{SE} 2.8$ vs. agammaglobulinemic $=$ $16.4 \pm \mathrm{SE} 2.2$ ). Because the data were skewed and demonstrated considerable variance, the significance of this difference was evaluated by nonparametric Mann-Whitney U test (13). Despite the decreased mean response in the agammaglobulinemic populations, there was no significant difference between the two populations $(z=1.26, P$ $>0.15$ ).

Protein synthesis. The accumulation of radioactive amino acid into both cellular and supernatant protein in six agammaglobulinemic and six normal cultures is seen in Fig. 3. On the left are cultures stimulated by PHA. On the right are unstimulated cultures. There was essentially linear accumulation of leucine $-{ }^{14} \mathrm{C}$ into protein in both populations, whether stimulated or not. The cultures stimulated by PHA, however, showed a threefold increase in the quantity of newly synthesized "total" protein. The mean rate and standard deviation for the normal cultures are shown, but only the mean values of the agammaglobulinemic cultures are drawn for simplicity. The standard deviations of the agammaglobulinemic cultures were slightly larger but of similar mag- nitude to the normal. There was no essential difference between the two groups under similar experimental conditions.

The accumulation of radioactive amino acid into the extracellular protein in 11 agammaglobulinemic cultures and 13 normal cultures are seen in Fig. 4. On the left are cultures stimulated with PHA. On the right are unstimulated cultures. There was essentially linear accumulation of leucine- ${ }^{14} \mathrm{C}$ into supernatant protein in both populations of cells whether stimulated or not. The cultures stimulated with PHA similarly demonstrated a threefold increase in quantity of newly synthesized protein in the supernatant. The mean rate and standard deviation for the 13 normal cultures are shown but only the mean values of the agammaglobulinemic cell cultures are drawn. The standard deviations of the agammaglobulinemic cultures were of magnitude slightly larger but similar to the normal. The mean rates of accumulation of newly synthesized protein in the extracellular medium of both normal cell cultures and agammaglobulinemic cell cultures were virtually identical when examined under similar experimental conditions. 


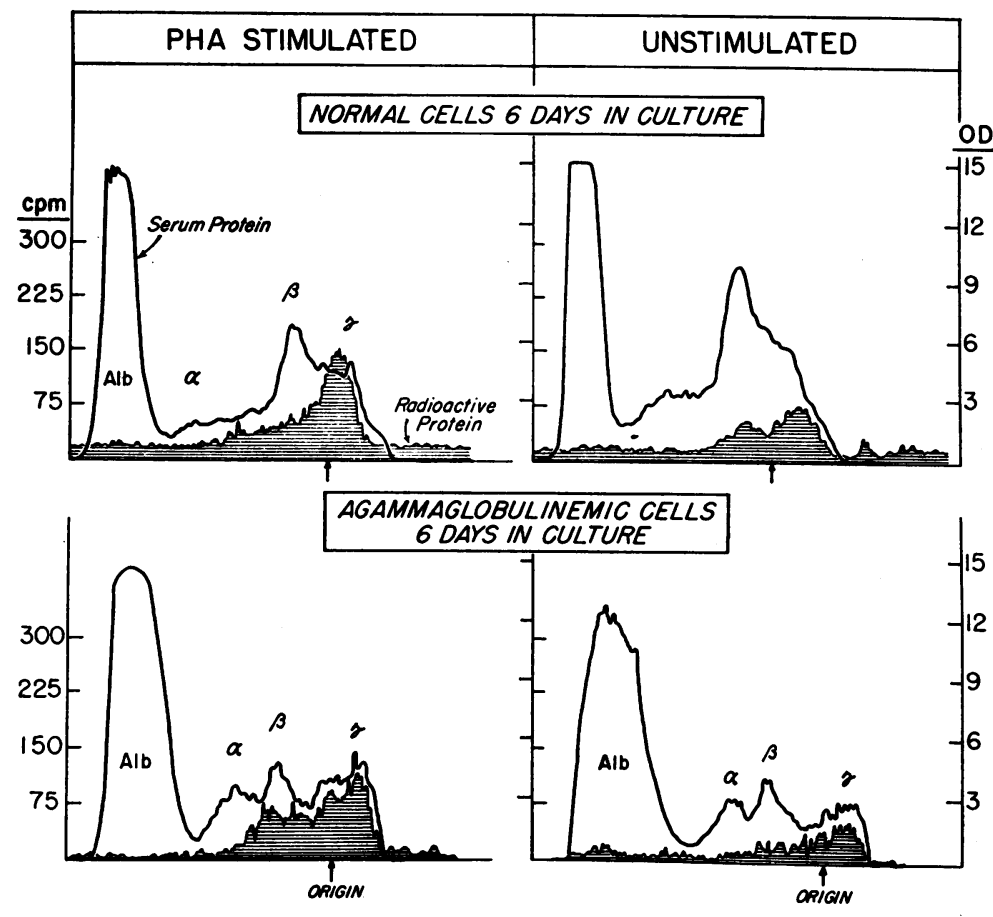

Figure 5 Electrophoretic characterization of newly synthesized extracellular protein produced by normal (upper) and agammaglobulinemic (lower) lymphocytes after 6 days in culture. Phytohemagglutinin-stimulated cells on left; unstimulated cells right. Serum protein in the culture is presented as a solid line. The distribution of newly synthesized protein is presented by the hatched area.
In the PHA-stimulated normal cultures 26.3 $\pm \mathrm{sD} 6.5 \%$ of the newly synthesized total protein was found in the supernatant. Similar agammaglobulinemic cultures demonstrated $30.4 \pm \mathrm{SD}$ $8.0 \%$ of the radioactive protein in the supernatant. The unstimulated normal cultures contained 23.3 $\pm \mathrm{SD} 2.3 \%$ and similar agammaglobulinemic cul- tures $40.2 \pm \mathrm{SD} 21.8 \%$ of the total radioactive protein in the extracellular supernatant. There was no significant difference between the two experimental conditions or the two clinical populations (for the PHA-stimulated cultures $t=0.0924, P$ $>0.15$; for the unstimulated cultures $t=1.7074$, $P>0.05)$.
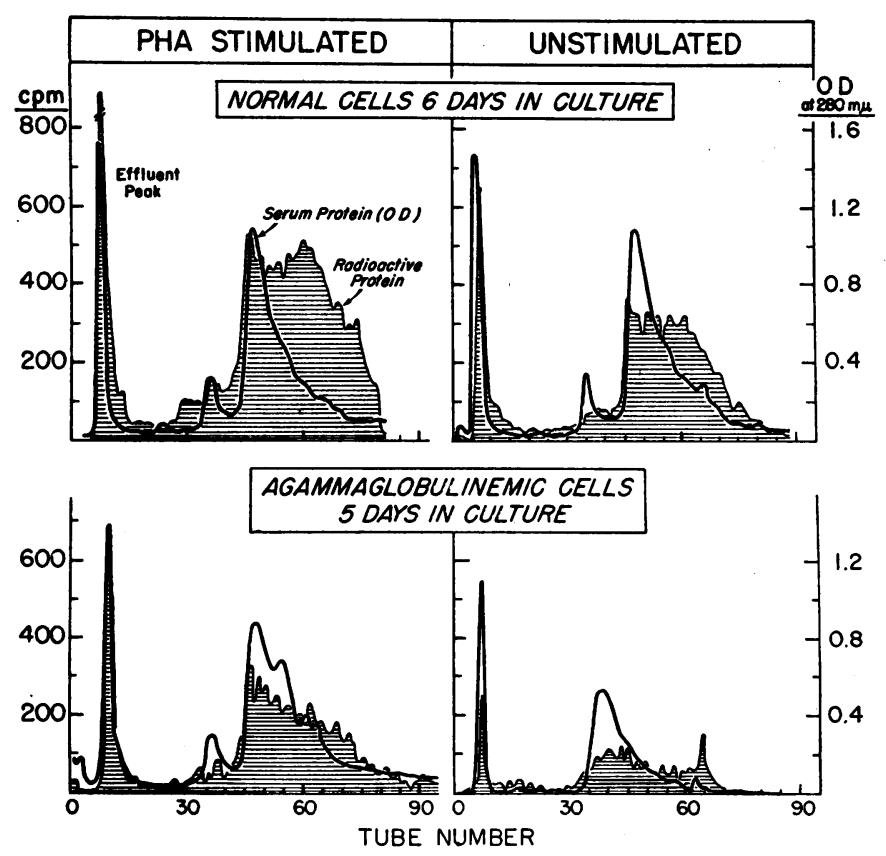

842

S. R. Cooperband, F. S. Rosen, and S. Kibrick
Figure 6 DEAE-cellulose chromatographic distribution of newly synthesized, extracellular protein produced by normal (upper) and agammaglobulinemic (lower) lymphocytes after 6 and 5 days, respectively, in culture. Phytohemagglutinin-stimulated cultures are on the left; unstimulated cultures on the right. Serum protein in the culture is presented as a solid line. The distribution of newly synthesized protein is shown as the hatched area. 


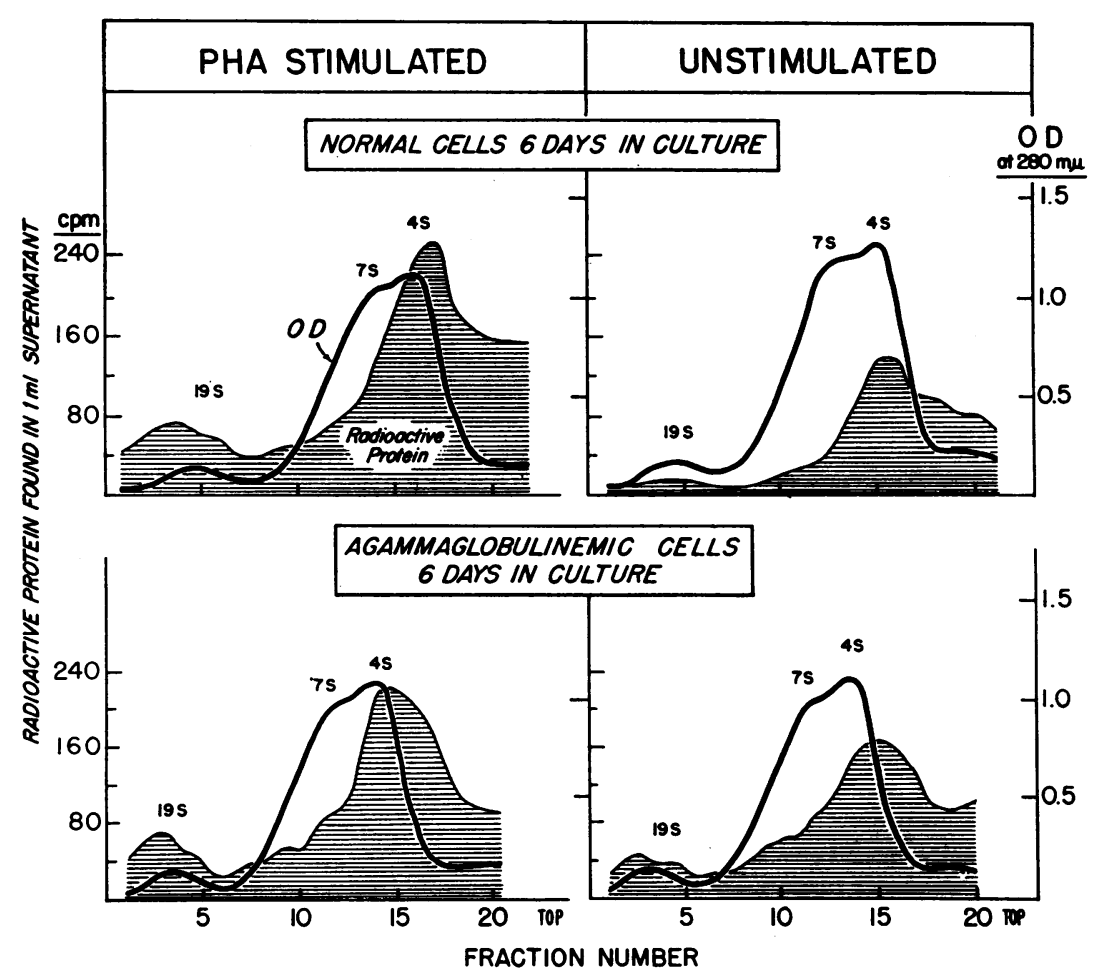

FIGURE 7 Sedimentation characteristics of newly synthesized, extracellular protein in sucrose density gradient ultracentrifugation. Distribution of normal cell supernatants in upper figures; agammaglobulinemic cell supernatants in lower figures. Phytohemagglutinin-stimulated cultures on left; unstimulated cultures, right. The three major sedimentation groups of serum proteins are specified over the solid line. The distribution of newly synthesized protein is shown as the hatched area.

Characterization of newly synthesized proteinelectrophoresis studies. Fig. 5 shows the electrophoretic distribution of radioactive protein found in the supernatants from both PHA-stimulated and unstimulated cultures. The upper figures are those obtained from cultures of normal lymphocytes. The lower figures are from cultures of agammaglobulinemic cells. The distribution of serum proteins present in the supernatant is superimposed. The positive poles are to the left. These studies were performed on the supernatants from 6-day old cultures. In all, the radioactive protein was seen to overlie the beta and gamma globulin region of the serum proteins, with the largest quantity of radioactivity in the gamma region. There was no qualitative difference between the electrophoretic analysis of the radioactive proteins found in the supernatant of normal cells and those from agammaglobulinemic cell cultures. Both PHA-stimulated and unstimulated cultures show qualitatively similar radioactive protein distributions. Studies upon samples isolated from cultures of different age (between 3-10 days) were also similar.

$D E A E$-cellulose chromatography. The distribution of radioactive protein after DEAE-cellulose chromatography is plotted on Fig. 6. As before, normal cell cultures are seen above, agammaglobulinemic cell cultures seen below; those with PHA stimulation on the left, no stimulation on the right. Approximately $15 \%$ of the newly synthesized protein was found in the proteins which did not bind to the DEAE-cellulose column (effluent peak) at $\mathrm{pH} 8.0,0.01 \mathrm{~m}$ phosphate. The majority of the radioactive proteins were eluted at lower $\mathrm{pH}$ and high salt concentrations. The radioactive protein in the supernatant of agammaglobulinemic cultures was similar to that in normal 
cultures. The distribution was similar in cultures with and without PHA. Varying the time in culture did not alter the chromatographic profile.

Sucrose density gradient ultracentrifugation. Sedimentation coefficients of the newly synthesized extracellular protein were estimated by preparative ultracentrifugation in sucrose density gradients. Fig. 7 illustrates the results of these analyses from lymphocyte cultures which were incubated with and without PHA. As before, the distribution of the serum protein in the media, determined by optical density at $280 \mathrm{~m} \mu$, was plotted for reference. The sedimentation coefficients for the major serum protein groups are noted at approximately $19 \mathrm{~S}, 7 \mathrm{~S}$, and $4 \mathrm{~S}$. The majority of the newly synthesized protein sedimented more slowly than the $4 \mathrm{~S}$ serum protein peak; however, approximately $5 \%$ of the radioactive proteins sedimented at $19 \mathrm{~S}$, and $15 \%$ at $7 \mathrm{~S}$. The distribution of newly synthesized protein was similar in agammaglobulinemic and normal cell cultures, and was not altered significantly by stimulation with PHA, or by time in culture.
IgG synthesis. The electrophoretic, chromatographic, and ultracentrifugation analyses of radioactive protein suggested that one of the proteins produced by the lymphocytic cells was similar to $7 \mathrm{~S}, \gamma \mathrm{G}$ globulin. Isolation of this specific protein was accomplished by means of immunocoprecipitation with anti-IgG and carrier $\gamma \mathrm{G}$ globulin. The quantity of newly synthesized protein was determined from the quantity of radioactivity in this precipitate. The mean concentration of the precursor leucine pool in these cultures had been previously determined to be 0.84 mmoles. ${ }^{1}$ For the present experiment, the specific activity of the leucine (based on this value) was $6.1 \mathrm{mc} / \mathrm{mmole}$. Since leucine represents $7 \%$ of the $\gamma \mathrm{G}$ molecule (14), the total quantity of $\gamma \mathrm{G}$ globulin isolated could be determined after an appropriate correction for a $10 \%$ counting efficiency. The quantity of $\gamma \mathrm{G}$ globulin synthesized with or without PHA stimulation in each of the 11 agammaglobulinemic lymphocyte cultures is seen in Fig. 8. The individual donors are identified by initials. Each culture was sacrificed sequentially and the accumu-

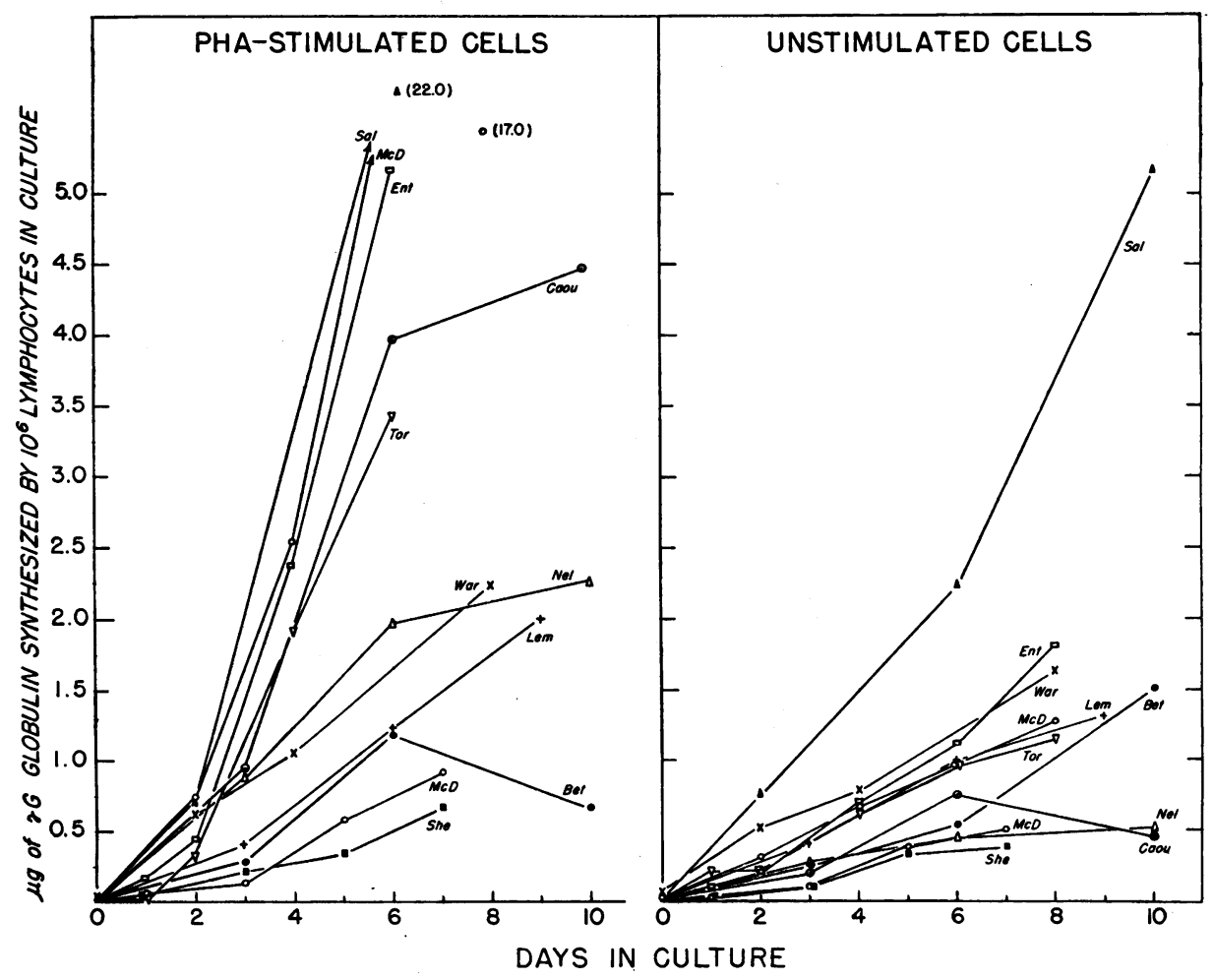

FIGURE 8 Accumulation of newly synthesized $\gamma \mathrm{G}$ globulin in the extracellular medium of agammaglobulinemic lymphocytes in culture. The individual donors are noted by initial. 


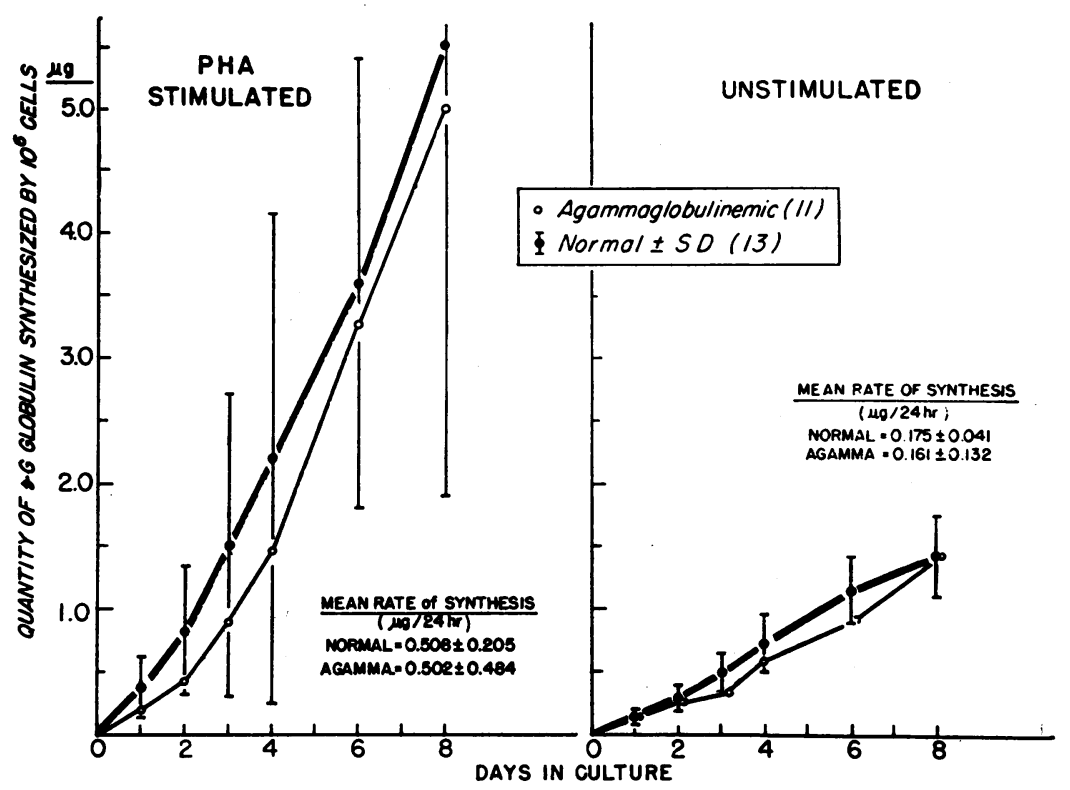

Figure 9 Comparison of the mean rates of accumulation of $\gamma \mathrm{G}$ globulin by 13 normal and 11 agammaglobulinemic lymphocyte cultures. Phytohemagglutininstimulated cultures on left, unstimulated cultures on right. The mean daily rate of $\gamma \mathrm{G}$ globulin synthesis for both populations under the two experimental conditions is inserted.

lated quantity of $\gamma \mathrm{G}$ was determined. This is plotted as a function of time in the culture.

The mean quantity \pm the standard deviation of $\gamma \mathrm{G}$ globulin produced by the 11 agammaglobulinemic cultures is contrasted to similar data obtained from 13 cultures of normal cells in Fig. 9. There was no significant difference in the quantity of $\gamma \mathrm{G}$ globulin synthesized between the normal and agammaglobulinemic cultures examined $(P<$ $0.02)$. Both cultures were capable of being stimulated to produce a threefold increase in the quantity of $\gamma \mathrm{G}$ globulin. Under PHA stimulation $1 \times 10^{6}$ normal cells produced $0.508 \pm 0.205 \mu \mathrm{g}$ of $\gamma \mathrm{G}$ globulin $/ 24 \mathrm{hr}$; the agammaglobulinemic cell cultures produced $0.502 \pm 0.484 \mu \mathrm{g} / 24 \mathrm{hr}$. Unstimulated normal cultures produced $0.175 \pm$ $0.041 \mu \mathrm{g}$ of $\gamma \mathrm{G}$ globulin $/ 10^{6}$ cells per $24 \mathrm{hr}$ and unstimulated agammaglobulinemic cells produced a similar quantity $\left(0.161 \pm 0.132 \mu \mathrm{g} / 10^{6}\right.$ cells for $24 \mathrm{hr}$ ).

\section{DISCUSSION}

These studies support the idea that the circulating lymphocytes from patients with agammaglobulinemia are capable of proliferating in vitro under the stimulus of PHA or under the stimulus of a number of specific antigenic substances. These cells are capable of recognizing antigens, and respond to this recognition by the synthesis of DNA. There was no statistical difference in the intensity of response between agammaglobulinemic and normal lymphocyte cultures to either immune stimulus or to the nonspecific mitogen-phytohemagglutinin.

The rate of accumulation of newly synthesized protein in the cells and extracellular media of these cultures was similar in both agammaglobulinemic and normal cell cultures. The character of the extracellular protein synthesized by the agammaglobulinemic cells was also similar to that seen in normal cultures. As with normal cells, increased quantities of protein could be produced by stimulating agammaglobulinemic cells with PHA. A small proportion of the newly synthesized protein in the extracellular media of both normal and agammaglobulinemic cell cultures had the characteristics of $\gamma \mathrm{G}$ globulin by both biochemical and immunochemical characterization. The quantity of $\gamma \mathrm{G}$ globulin produced by agammaglobulinemic cultures was identical with that produced by the normal cell cultures. The quantity of $\gamma \mathrm{G}$ globulin synthesized could be increased by stimulation of 
the cells with PHA. From these data, it would appear that neither the structural nor regulatory genetic apparatus necessary for the synthesis of $\gamma \mathrm{G}$ globulin is altered in the peripheral blood lymphocytes of these patients.

These data are in contrast to those reported by Fudenberg and Hirschhorn (15), Cline and Fudenberg (16), and Elves, Roath, and Israëls (17). They have reported that lymphocytes have failed to proliferate upon stimulation with antigen or PHA, and failed to produce $\gamma$-globulin. These experiments however were carried out mostly during the first $24-72 \mathrm{hr}$ in culture. During this time period the biochemical differences between stimulated and unstimulated cells are minimal. In our experiments, it has taken 5-7 days in culture for maximal differences in response to be evident. The rate of protein synthesis in the agammaglobulinemic cultures during the first $48 \mathrm{hr}$ was somewhat slower than occurred in the normal cell cultures. This reduced protein production, however, was not statistically significant and had even less statistical meaning when incorporated into the data for the full length of the cultures. However, it is possible that the events which occur in vitro during the first $24-72 \mathrm{hr}$ of the agammaglobulinemic cultures are different from those which occur in the normal cell cultures, and represent an "escape" from an in vivo suppressing environment.

A number of studies on cellular hypersensitivity in agammaglobulinemic patients suggest that lymphocytes from agammaglobulinemic patients function normally. It is well documented that patients with these clinical disorders are capable of expressing skin sensitivity to mumps and other viral agents (18), to Monilia antigens (19), and to tuberculin after Colmette-Guérin bacillus (BCG) immunization (20). They may be actively sensitized with such chemicals as 2,4-dinitrochlorbenzene (21). Although there is some evidence that graft rejection may be delayed in patients with agammaglobulinemia, second set rejection is intact in these individuals (22). Thus, our data, demonstrating similarities in proliferative response and character of protein synthesized, is in more general agreement with the clinical observations on the activity of lymphocytic cells from agammaglobulinemic patients.
The quantity of $\gamma \mathrm{G}$ globulin produced by lymphocytes is relatively small and raises the possibility that lymphocytes are the source of the small quantities of immunoglobulins found in the serum of almost all patients with agammaglobulinemia. It is difficult to determine the exact contribution of lymphoid cells to the total $\gamma \mathrm{G}$ globulin synthesis, primarily because there are no adequate data concerning the numbers of cells available for synthesis in the intact organism. If we accept MacGregor and Gowans' (23) data on rats as a suitable model, then a $70 \mathrm{~kg}$ man would contain approximately $10^{12}$ circulating lymphocytes. Utilizing our observations on the rate of gammaglobulin synthesis, we would estimate that unstimulated lymphocytes in circulation would produce approximately $50 \mathrm{mg}$ of $\gamma \mathrm{G} / 24 \mathrm{hr}$. This is a very minor portion of the $2.5-3.0 \mathrm{~g} /$ day produced per $24 \mathrm{hr}$ by a $70 \mathrm{~kg}$ normal man (24), but could account for serum concentrations of gamma globulin similar to those observed in agammaglobulinemic individuals.

On the basis of our data, circulating lymphocytes from patients with agammaglobulinemia appeared entirely normal in vitro. The rate of protein $\gamma$-globulin synthesis and the intensity of the proliferative response to both PHA and antigens was similar in all populations studied. The character of the protein produced after transformation by PHA was not different in the agammaglobulinemic cell cultures. On the basis of experiments reported, it would appear unlikely that the circulating lymphocytes are involved in the genetic deficiency responsible for the clinical disorder. Since most of this study was performed with lymphocytes from donors with congenital X-linked agammaglobulinemia, we do not have sufficient data to determine whether cells from patients with acquired or sporadic agammaglobulinemia are different. However, there was no marked differences in the data from three such donors.

\section{ACKNOWLEDGMENTS}

We gratefully acknowledge the technical assistance of M. A. Kennedy and M. Grant.

Dr. F. S. Rosen is a recipient of Career Development Award 1-K3-AM 19650.

This paper was supported by grants AM-05589, AM09812, AI-AM-05877, FR-00128, and AI-04305 of the U. S. Public Health Service. 


\section{REFERENCES}

1. Pearmain, G., R. R. Lycette, and P. H. Fitzgerald. 1963. Tuberculin induced mitosis in peripheral blood leucocytes. Lancet. 1: 637.

2. Schrek, R. 1963. Cell transformation and mitosis produced in vitro by tuberculin purified protein derivative in human blood cells. Am. Rev. Respirat. Diseases. 87: 734 .

3. Cooperband, S., A. Nahmias, and S. Kibrick. 1964. Metabolic activity of human blood lymphocytes during immune and non-specific stimulation. Annual Meeting of the American Rheumatism Association, San Francisco. Arthritis Rheumat. 7: 303.

4. Bach, F., and K. Hirschhorn. 1963. Gamma globulin projuction by human lymphocytes in vitro. Exptl. Cell Res. 32 : 592.

5. Turner, K. J., and I. J. Forbes. 1966. Synthesis of proteins by human leukocytes in vitro. II. Chemical characterization. J. Immunol. 96: 926.

6. Fahey, J. L., and M. E. Lawrence. 1963. Quantitative determination of $6.6 \mathrm{~S} \gamma$-globulins, $\boldsymbol{\beta}_{\mathbf{2}}$ globulins and $\gamma_{1}$-macroglobulins in human serum. J. Immunol. 91: 597.

7. Mellman, W. J. 1965. Human peripheral blood leukocyte cultures. In Human Chromosome Methodology. J. J. Yunis, editor. Academic Press, Inc., New York. 21.

8. Cooperband, S. R., J. A. Green, M. Kennedy, and M. Grant. 1967. Dissociation and inhibition of the stimulatory effect of phytohemagglutinin on protein and DNA synthesis in human lymphocyte cultures. Nature. 214: 1240.

9. Latham, W. C., C. P. Jenness, R. J. K. Timperi, C. B. H. Michelsen, E. M. Zipilivan, G. Edsall, and J. H. L. Ley, Jr. 1965. Purification and characterization of tetanus toxoid and toxin. I. Fractionation of tetanus toxoid by gel filtration. J. Immunol. 95: 487.

10. Kahan, F. M. 1960. Purification and measurement of microgram amounts of radioactive nucleic acids and protein from animal cells in tissue culture. Anal. Biochem. 1: 107.

11. Fahey, J. L., P. F. McCay, and M. Goulian. 1958. Chromatography of serum proteins in normal and pathologic sera: The distribution of protein-bound carbohydrate and cholesterol, siderophilin, thyroxinbinding protein, $\mathrm{B}_{12}$-binding protein, alkaline and acid phosphatases, radio-iodinated albumin and myeloma proteins. J. Clin. Invest. 37: 272.
12. Edelman, G. M., H. G. Kunkel, and E. C. Franklin. 1958. Interaction of the rheumatoid factors with antigen-antibody complexes and aggregated gamma globulin. J. Exptl. Med. 108: 105.

13. Siegel, S. 1956. Non-parametric Statistics for the Behavioral Sciences. McGraw Hill Book Company, New York. 116.

14. Cohen, S., and R. R. Porter. 1964. Structure and biologic activity of immunoglobulins. Adzan. Immunol. 4: 287.

15. Fudenberg, H. H., and K. Hirschhorn. 1964. Agammaglobulinemia: the fundamental defect. Science. 145: 611.

16. Cline, M. J., and H. H. Fudenberg. 1965. Defective RNA synthesis in lymphocytes from patients with primary agammaglobulinemia. Science 150: 1311.

17. Elves, M. W., S. Roath, and M. C. G. Israëls. 1964. Failure of lymphocytes from hypogammaglobulinaemic subjects to transform in culture. Brit. Med. J. 2: 1051.

18. Gitlin, D., C. A. Janeway, L. Apt, and J. M. Craig. 1959. Agammaglobulinemia. In Cellular and Humoral Aspects of the Hypersensitive State. H. S. Lawrence, editor. Hoeber-Harper, New York. 375.

19. R. A. Good, and S. J. Zak. 1956. Disturbances in gamma globulin synthesis as "experiments of nature." Pediatrics. 18: 109.

20. Kulneff, N., K. O. Pedersen, and J. Waldenstrom. 1955. Drei Falle von Agammaglobulinamie ein klinischer, genetischer und physikalisch-chemischer Beitrag zur Kenntnis des Proteinstoffwechsels. Schweiz. Med. Wochschr. 85: 363.

21. Porter, H. M. 1957. Immunologic studies in congenital agammaglobulinemia with emphasis on delayed hypersensitivity. Pediatrics. 20: 958.

22. Schubert, W. K., R. Fowler, Jr., L. W. Martin, and C. D. West. 1960. Homograft rejection in children with congenital immunological defects: agammaglobulinemia and Aldrich syndrome. Transplant. Bull. 26: 125.

23. McGregor, D. D., and J. L. Gowans. 1963. The antibody response of rats depleted of lymphocytes by chronic drainage from the thoracic duct. J. Exptl. Med. 117: 303 .

24. McFarlane, A. S. 1964. Metabolism of plasma proteins. In Mammalian Protein Metabolism. H. N. Munro and J. B. Allison, editors. Academic Press, Inc., New York. 1: 297. 